\title{
Distribution and identification of the White-collared Kite Leptodon forbesi and the juvenile plumages of the Gray-headed Kite Leptodon cayanensis
}

\author{
Rafael Dantas Lima ; Willian Menq² \& Frederick Pallinger ${ }^{3}$ \\ 1 Universidade do Estado do Rio Grande do Norte (UERN). Mossoró, RN, Brasil. \\ ORCID: http://orcid.org/0000-0002-5583-3902. E-mail: rafael-dlima@hotmail.com \\ 2 Campo Grande, MS, Brasil. ORCID: http://orcid.org/0000-0002-9060-3715. E-mail: willianmenq@gmail.com \\ 3 São Paulo, SP, Brasil. ORCID: http://orcid.org/0000-0002-9420-2409. E-mail: fjpallinger@gmail.com
}

\begin{abstract}
The genus Leptodon encompasses two Neotropical raptor species. The more widely-distributed Gray-headed Kite (Leptodon cayanensis) occurs in a vast area of Neotropical region, while the White-collared Kite (Leptodon forbesi) is endemic of the Atlantic Forest of northeastern Brazil, but there are some questions about the extent of its geographic distribution and about its sympatry with its congener. Here we present a review of the geographic distribution and the diagnoses of $L$. forbesi, correcting recent records based on misidentifications. We also clarify the main features of juvenile and subadult plumage of Leptodon raptors and describe new phases of juvenile plumage.
\end{abstract}

Key-Words. Aves; Accipitriformes; Endangered; Pernambuco Center of Endemism; Atlantic Forest.

\section{INTRODUCTION}

The genus Leptodon Sundevall, 1836 encompasses two Neotropical raptor species - the Gray-headed Kite Leptodon cayanensis (Latham, 1790) and the White-collared Kite Leptodon forbesi (Swann, 1922). The first occurs in a vast area of Neotropical region, from Mexico to Paraguay and north of Argentina, including almost the totality of Brazilian extension (Thiollay, 1994; FergusonLees \& Christie, 2001). The second species, L. forbesi, occurs in the Atlantic Forest of northeastern Brazil, but there are some questions about the extent of its geographic distribution. There is no doubt on the occurrence of $L$. forbesi throughout the Pernambuco Center of Endemism (PCE) - the Atlantic Forest north of the São Francisco river, from Alagoas to Rio Grande do Norte states - but some authors suggest a wider distribution, south of the São Francisco river in Sergipe and Bahia states, occurring in sympatry with L. cayanensis (Seipke et al., 2011; Leite et al., 2017; Pereira et al., 2019).

Both species show strong plumage polymorphism during the juvenile stage, but while juvenile plumages of $L$. cayanensis were well known (Foster, 1971; Ferguson-Lees \& Christie, 2001; Dénes, 2009), the lack of knowledge about plumage sequences of $L$. forbesi and the paucity of studies in the field still generate errors of identification. Since its description and due the lack of comparative material available in museums, several authors questioned the taxonomic validity of $L$. forbesi, and the sole type-specimen was treated as an immature form or even a variation of L. cayanensis (Hellmayr, 1929; Hellmayr \& Conover, 1949; Brown \& Amadon, 1968; Pinto, 1978; Sick, 1997); however its validity as a full species is now firmly solved (Dénes et al., 2011). Here we review the records of $L$. forbesi in order to shed light on its geographic distribution, and clarify some features of the juvenile and subadult plumage of both species.

\section{METHODS}

We revised all available literature (see a compilation in Pereira et al., 2019) and 4,681 photographic and filming records of Leptodon raptors in online databases (Wikiaves and Macaulay Library; all published media until August 2020). Wikiaves records are referred throughout the text by the "WA access number". We observed the age and plumage patterns in each documented record based on literature descriptions (e.g., Thiollay, 1994; Ferguson-Lees \& Christie, 2001; Seipke et al., 2011) and we also searched for additional diagnostic features for Leptodon species. 


\section{RESULTS AND DISCUSSION}

\section{Age and color polymorphism}

Both species of Leptodon show strong plumage polymorphism only during the juvenile stage, being able to mimic larger and more powerful birds of prey (Spizaetus spp.) to protect themselves from attacks or predation (Prum, 2014; Leightom et al., 2018). Juvenile with mimetic plumage have yellow bare parts (cere, legs and toes) and its intensity may varies according to its age. In subadults, the bare parts are light-yellow while in adults the cere is bluish-gray and feet and toes are gray or greyish-yellow (Ferguson-Lees \& Christie, 2001). The yellow-colored bare parts in juvenile individuals are easy visualization features in the field and remain visible even in collected specimens, making age identification an easy task.

We found four distinct phases, including two undescribed (3 and 4), in the juveniles of L. cayanensis: (1) the light phase, a probable mimicry of the Black-and-White Hawk-eagle Spizaetus melanoleucus, with white belly and

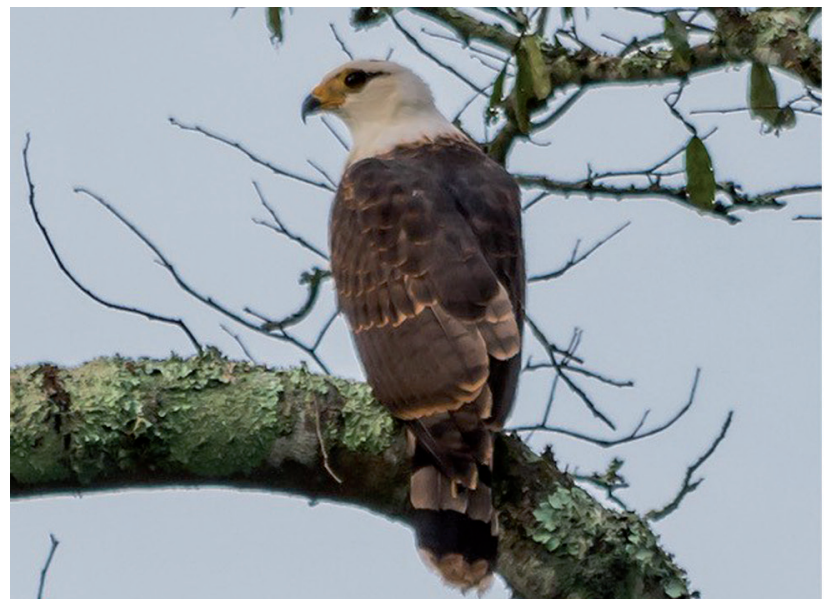

dark back, and a black face mask, besides a small dark crown (Fig. 1); (2) the striated phase, also named as dark phase by other authors (Foster, 1971), representing a larger variation and might occur in different color combinations, usually with dark brown back and white belly with dark vertical stripes (see Foster, 1971; Dénes, 2009); (3) the melanistic phase, a possible mimicry of the Black Hawkeagle Spizaetus tyrannus, in which the bird is almost entirely black with a white streaked belly (Fig. 2); and (4) the mimetic phase of the Ornate Hawk-eagle Spizaetus ornatus (or "ornatus phase") recently discovered in an individual from Pará, Brazil (Fig. 3). This latter differs completely from the striated phase as it shows belly horizontal stripes instead of the vertical ones of the striated phase, besides the head and neck plumage perfectly mimicking Spizaetus ornatus, including a well-developed crest (Fig. 3). Records of juveniles of $L$. forbesi are still very scarce. We found only five records of juvenile birds in the light (see Fig. 1, WA1232815 and WA3064745) and striated (see WA2327515 and WA2317774) phases. Both phases are apparently identical to the corresponding phases in L. cayanensis.

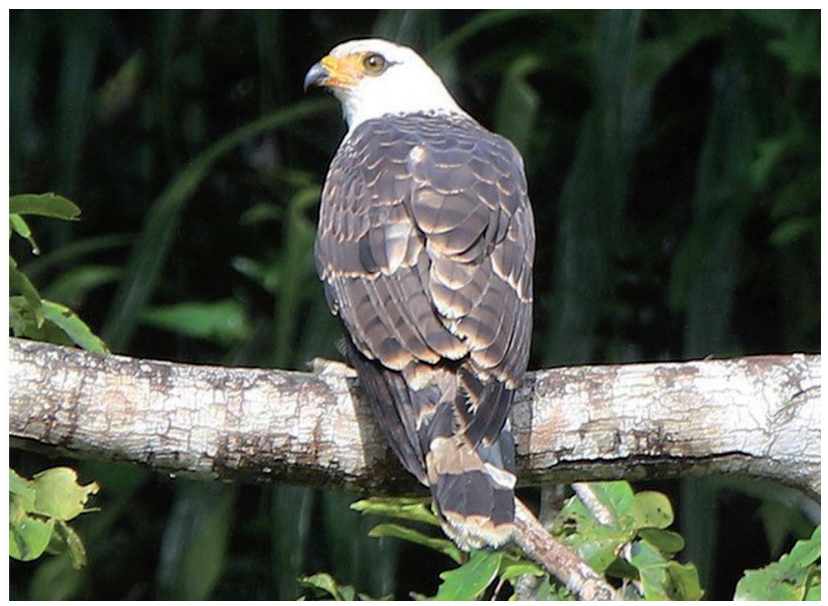

Figure 1. Juvenile light phase in both species. Leptodon cayanensis (left) photographed in Pirajuí, São Paulo, and Leptodon forbesi (right) photographed in Santa Rita, Paraíba. Photos by Rafael Martins and lan Thompson, respectively.
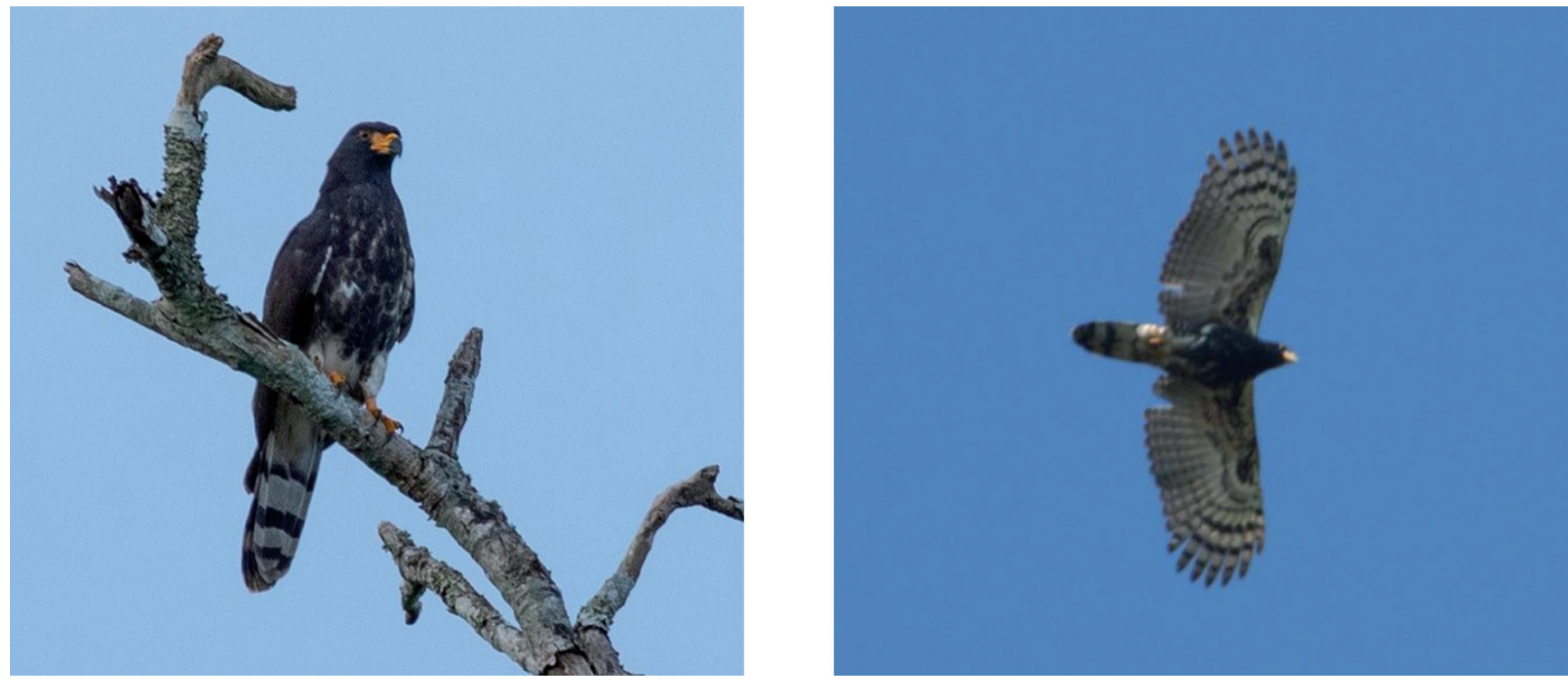

Figure 2. Juvenile individuals of Leptodon cayanensis in the melanistic phase, photographed in Rio Maya Lodge, Belize (left), and in Campinas, São Paulo (right). Photos by Aaron Juan and Guilherme Ortiz, respectively. 

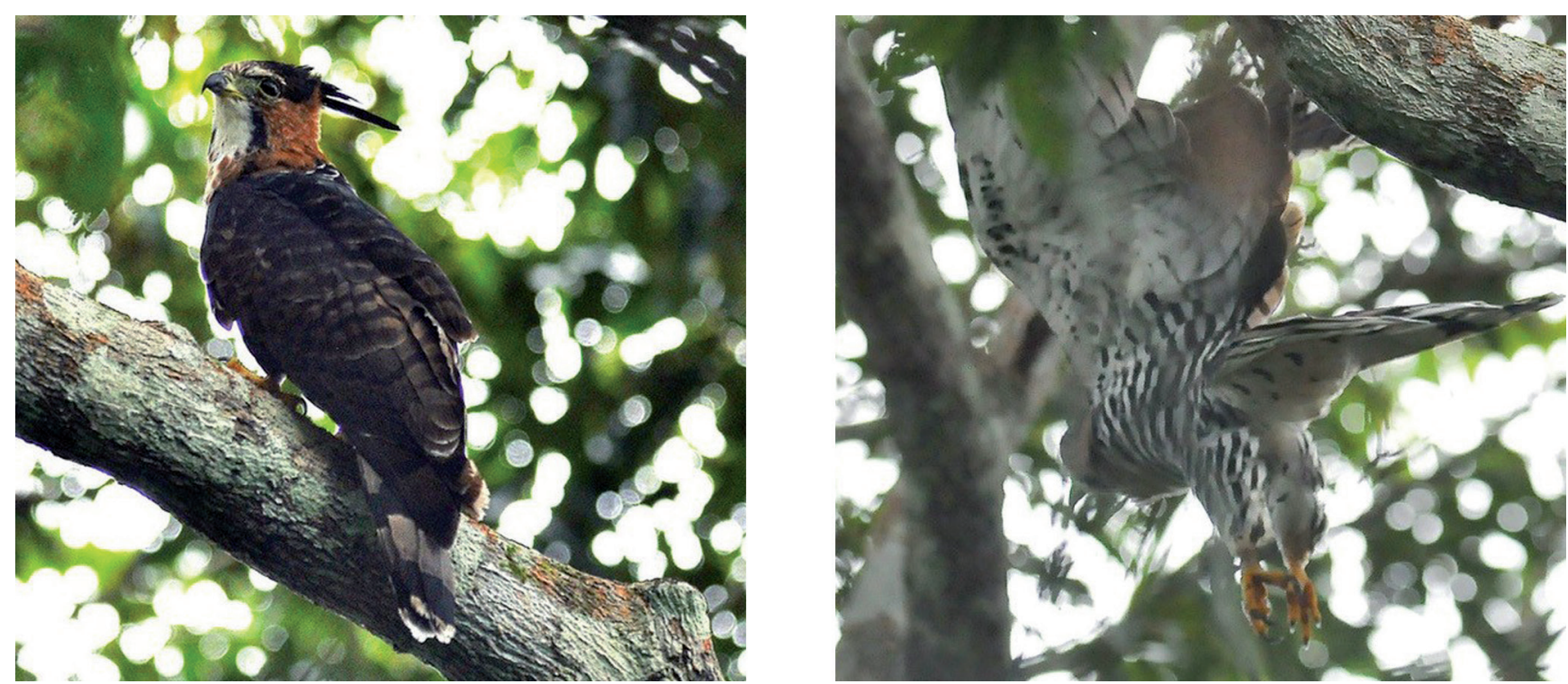

Figure 3. Juvenile individual of Leptodon cayanensis in mimetic phase of Spizaetus ornatus, photographed in Belterra, Pará. Photos by Robson Czaban.

\section{Identification}

By applying diagnostic features for both L. forbesi and L. cayanensis, we found published misidentifications (see the section "records and geographic distribution"). Even though the species' diagnoses and morphological variations have been recently revised (Dénes et al., 2011), besides the elaboration of an identification plate for its distinction from other species (Seipke et al., 2011), some recently published records show the importance of a reinforcement for the accuracy in the identification of Leptodon raptors.

Two plumage features proved to be the best to identify both species, as they occur in all individuals of each species. The first is the coloration of underwing coverts. All records of $L$. forbesi in adult plumage show all-white underwing coverts (sometimes with black patches in the greater coverts, vestiges of subadult plumage; see Fig. 4F), while all $L$. cayanensis in adult plumage show almost completely black underwing coverts (Fig. 4). The second feature is the coloration of hindneck and mantle. All records of $L$. forbesi in adult and subadult plumage show white hindneck and black mantle with white spots (white-tipped feathers), while all L. cayanensis show gray hindneck and black mantle (Seipke et al., 2011). Other features as the color of the leading edges can be useful to distinguish both species, being usually white in L. forbesi and black in L. cayanensis, but these features should be used with caution or in association with other features since they show a little variation (Seipke et al., 2011).

Barring degree in ventral surface of the secondaries have been suggested as diagnostic character (Seipke et al., 2011). According to these authors, L. cayanensis show noticeable barring on secondaries, unlike most $L$. forbesi which show almost unmarked secondaries. However, we found both patterns in both species. Most L. cayanensis we found had noticeably barred secondaries, but we also found several $L$. cayanensis with almost unmarked secondaries (e.g., WA1434545 and WA2319879). Meanwhile, most $L$. forbesi we found had almost unmarked second- aries, but we also found some $L$. forbesi with noticeably barred secondaries (e.g., WA2324199 and WA3630665). This suggests this character is not diagnostic. The number of white bars in the tail was also already suggested as a diagnostic feature (e.g., Grantsau, 2010), but it is highly variable and should not be used as a diagnostic feature (Seipke et al., 2011; pers. obs.)

Subadults of both species can be very similar, presenting white underwings coverts with some black spots (Figs. 4 and 5). Throughout successive feather molts the underwing coverts become even lighter and turning to completely white in L. forbesi, contrasting to full black in L. cayanensis (Fig. 4). In juvenile the species identification becomes more complicated due the polymorphism and mimicry of plumage. Little is still known about juvenile plumage of $L$. forbesi, as there is no juvenile specimen with mimetic plumage deposited in museum collections.

\section{Records and geographic distribution}

The first record attributed to $L$. forbesi outside the PCE occurred in Baturité Mountains, Ceará (Bankovics, 2003), but it was already corrected in a study on L. cayanensis's occurrence in Ceará state (Girão et al., 2013).

In the state of Sergipe, some records attributed to L. forbesi had their individuals misidentified (Pereira et al., 2014; Silva \& Lima, 2016). They show typical features of adult $L$. cayanensis as gray hindneck and underwing coverts predominantly black. A third record, a juvenile Leptodon kept in captivity at "Parque dos Falcões" was claimed to be $L$. forbesi, without indication of the bird's origin and without mentioning the used features to determine the species, only pinpointing some features that are correspondent in both species of the genus (Seipke et al., 2011). As juvenile individuals in light phase may be identical in both species (Fig. 1), we consider this record only at the genus level. Despite the previous misidentified records in Sergipe, more recent records show individuals with typical features of $L$. forbesi in this state 
(WA3608338 and WA3954496), depicting the sympatry between the two species (see below).

Finally, L. forbesi was also mentioned for Bahia state, where a subadult individual was photographed at São Sebastião do Passé municipality (Leite et al., 2017). The authors identified the bird mainly based on the pattern of underwing coverts and secondaries, and reported that a typical $L$. cayanensis was observed at the same forest fragment (Leite et al., 2017). The predominantly white pattern of underwing coverts with small black patches in carpal and axillar areas is observed in subadult individuals of both species (Fig. 5), and the pattern of the secondaries highlighted by the authors is an inconsistent character, being variable in distinct individuals. A subadult could be diagnosed based on the pattern of hindneck and mantle, but the authors had only a ventral view of the bird. Therefore, the only diagnostic features for this plumage stage are not visible in the photograph (see Leite et al., 2017), making them unable to claim it is $L$. forbesi. Besides, the matter of $L$. cayanensis in typical plumage having been observed at the same place only reinforces the expected conclusion that it was only a subadult $L$. cayanensis in its normal range. Several records of individuals in plumage comparable to this can be observed in many other places of $L$. cayanensis distribution (e.g., Fig. 5, WA626948 and WA3703073).

The revision of the records of Leptodon in NE Brazil strongly suggests that $L$. forbesi is not endemic of PCE,

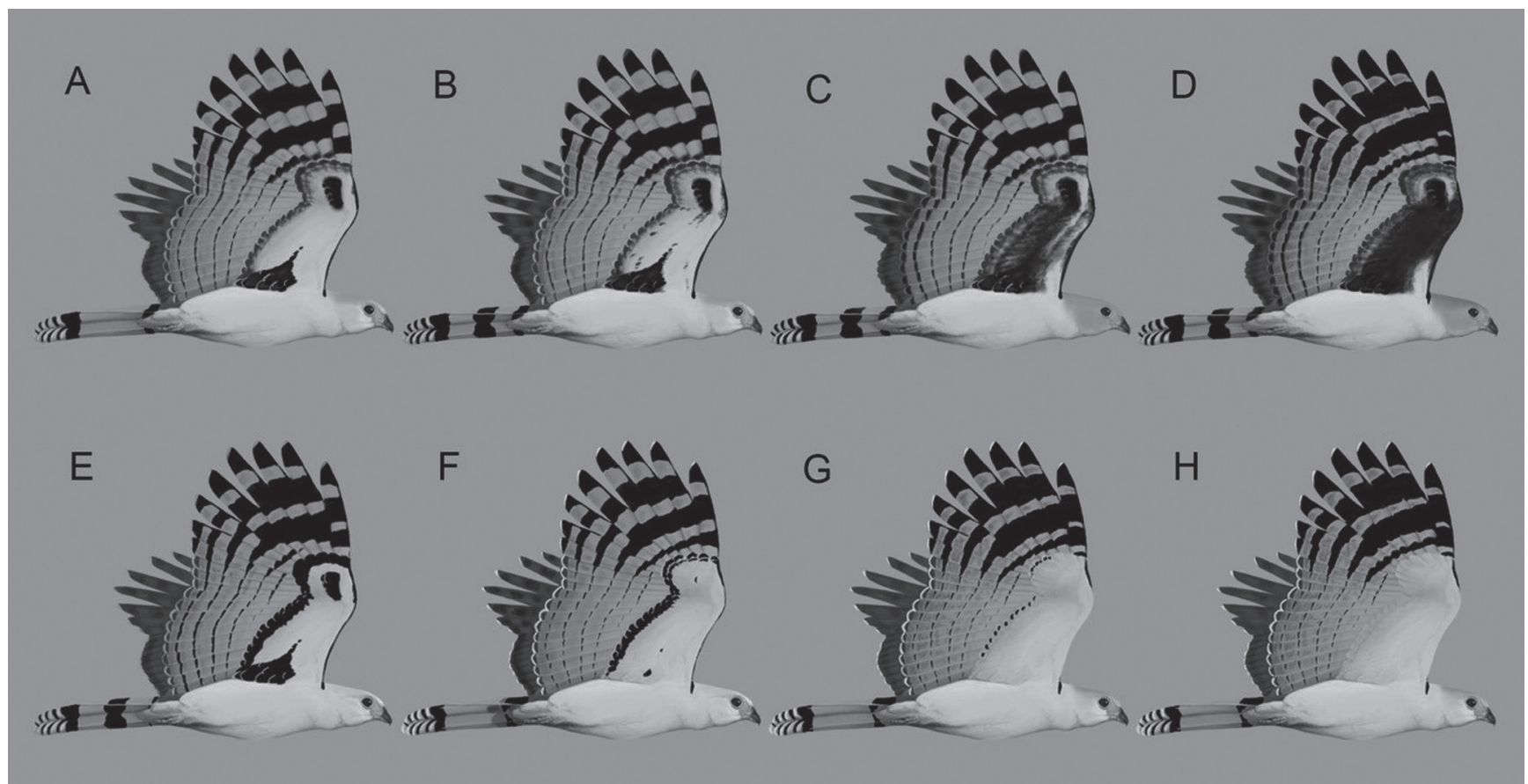

Figure 4. Leptodon cayanensis (A-D) and Leptodon forbesi (E-H) in successive molts. Individuals A and E show the subadult plumage (see photos in Fig. 5), which follows the mimetic juvenile one, and individuals $D$ and $H$ show the definitive adult plumage.
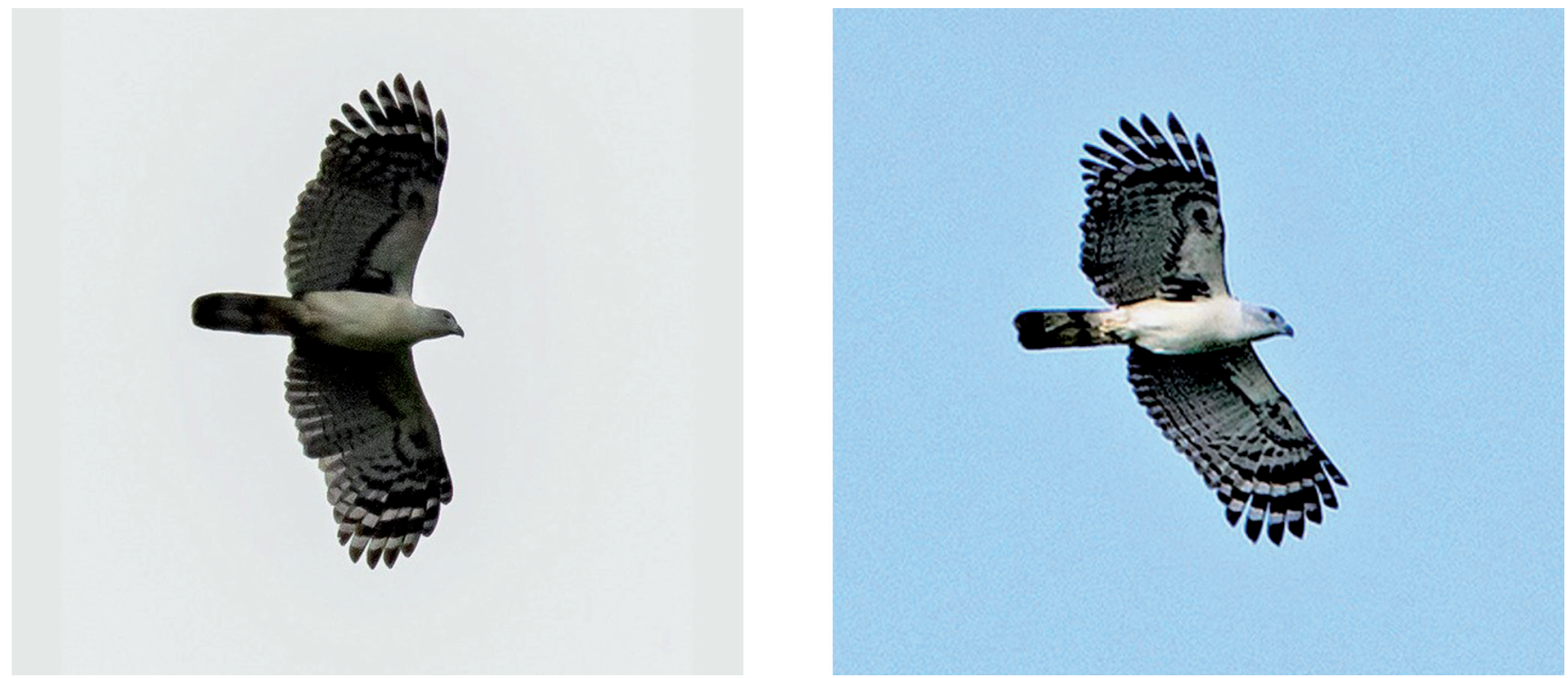

Figure 5. Subadult of Leptodon cayanensis (left) and Leptodon forbesi (right) showing the same plumage pattern. Records made in São Paulo (photo by Marcelo Figueiroa) and Alagoas (photo by Ciro albano), respectively. 
occurring in sympatry with $L$. cayanensis south of the São Francisco river in Sergipe (Fig. 6). Rivers delimit the geographic distribution of several Neotropical birds (Silva et al., 2004; Dantas et al., 2011; MaldonadoCoelho, 2012; Naka \& Brumfield, 2018), including forest raptors (Soares et al., 2019), and the São Francisco river represents a strong biogeographic break for several Atlantic Forest birds (e.g., Cabanne et al., 2008; Weir \& Price, 2011; Batalha-Filho et al., 2014; Rêgo et al., 2014;
Isler \& Maldonado-Coelho, 2017), but this is not the case for $L$. forbesi. The occurrence of adults with typical plumage of both $L$. forbesi and L. cayanensis in Sergipe raises the possibility of hybridization in this region, which can be hard to detect in field or by photos since hybrid birds may look like a subadult (Fig. 7). A genetic study of the populations in Alagoas and Sergipe would be welcome to clarify if there is introgression taking place in this region.

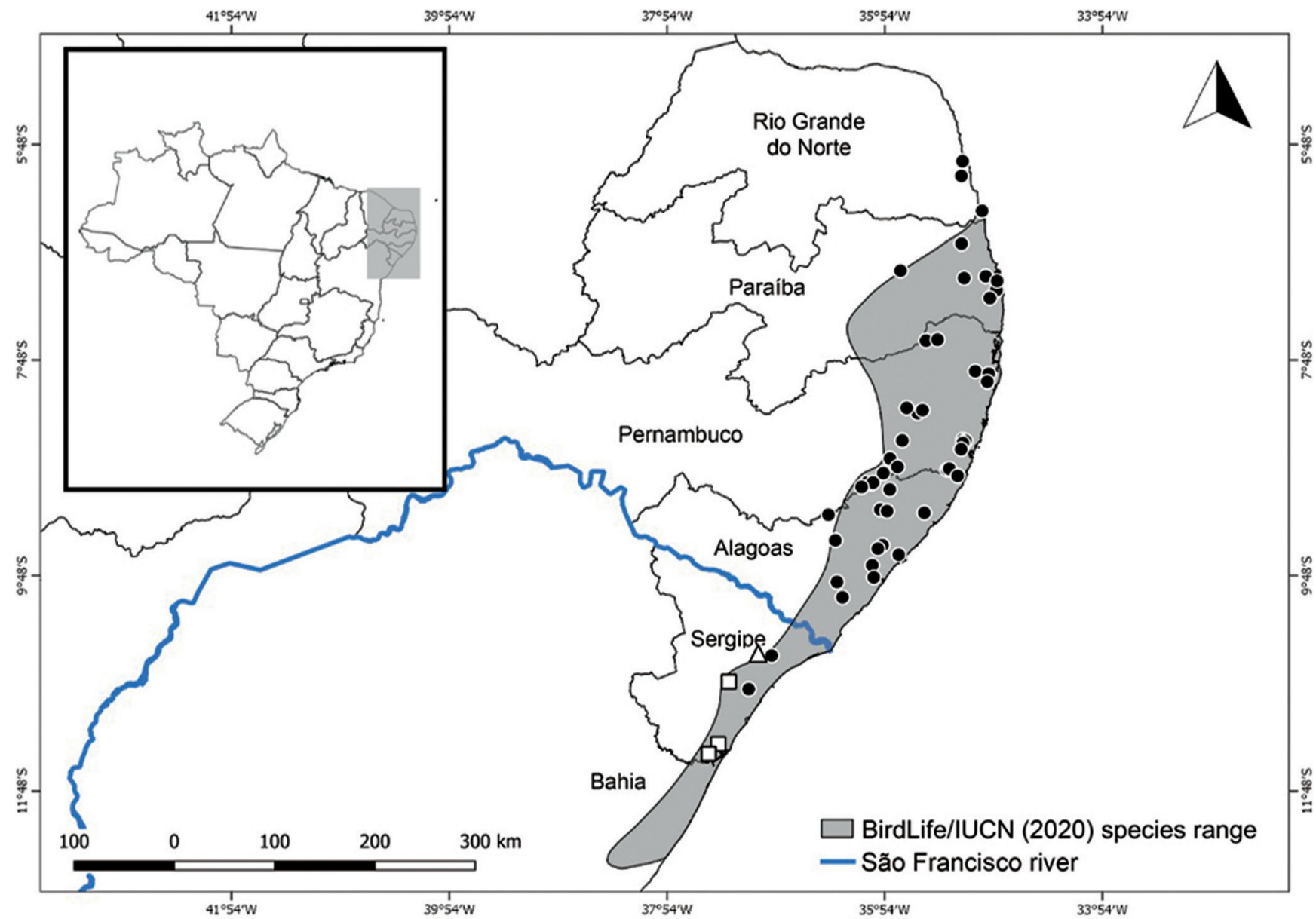

Figure 6. Updated distribution of Leptodon forbesi. Black circles represent all records of L. forbesi (see the localities in Pereira et al., 2019 and in the text above; the two circles in Sergipe are the photos WA3954496 and WA3608338), white squares represent the records of L. cayanensis in Sergipe (Pereira et al., 2014; Silva \& Lima, 2016; Fig. 7), and the white triangle represents a subadult Leptodon sp. (WA3548821). The range adopted by BirdLife/IUCN (2020) was based on the misidentified record in Bahia state.
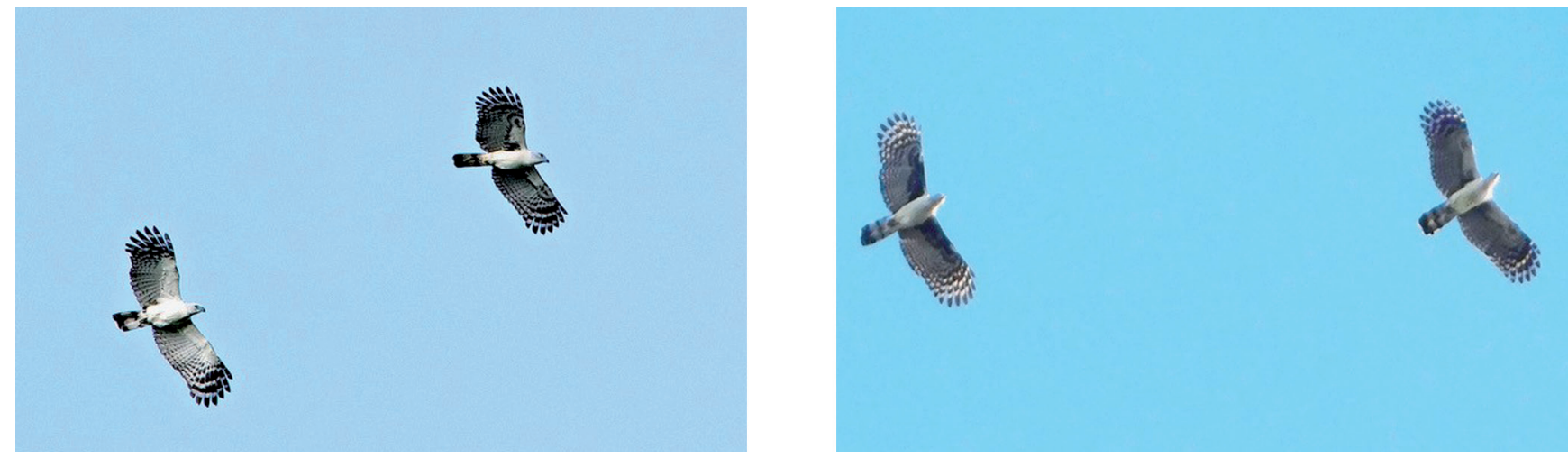

Figure 7. A pair of Leptodon in Alagoas (left) and another in Sergipe (right). Note that the pair in Alagoas has a typical adult L. forbesi along with a presumed subadult one, and the pair in Sergipe has a typical adult $L$. cayanensis along with a presumed subadult one; but the subadults are not identifiable. Photos by Ciro Albano and Cayo Lima, respectively. 
Finally, it is worth noting that Pereira et al. (2019) recently performed a distribution modeling of $L$. forbesi, but they considered a record in Rio Grande do Norte (WA2263455) as a probable dispersion. However, new and/or unpublished records (see Sagot-Martin et al., 2020) suggest that $L$. forbesi is resident in Rio Grande do Norte state. Sagot-Martin et al. (2020) reported sights at Parnamirim in January 2007 and July 2009, and the species was also recorded at Flona de Nísia Floresta reserve (WA3613114) in December 2019.

\section{ACKNOWLEDGMENTS}

We thank Luís Fábio Silveira, José Fernando Pacheco, and the anonymous reviewers for constructive comments that improved this paper. We also thank Aaron Juan, Cayo Lima, Ciro Albano, Guilherme Ortiz, Ian Thompson, Marcelo Figueiroa, Rafael Martins, and Robson Czaban for supplying us with their photographs.

\section{REFERENCES}

Bankovics, A. 2003. Distribution data of some bird species observed in Baturité mountains, Ceará, Brasil. Aquila, 109-110: 23-32.

Batalha-Filho, H.; Pessoa, R.O.; Fabre, P.; Fjeldsa, J.; Irestedt, M.; Ericson, P.G.P.; Silveira, L.F. \& Miyaki, C.Y. 2014. Phylogeny and historical biogeography of gnateaters (Passeriformes, Conopophagidae) in the South America forests. Molecular Phylogenetics and Evolution, 79: 422-432.

BirdLife International/International Union for Conservation of Nature and Natural Resources (IUCN). 2020. The IUCN Red List: White-collared Kite Leptodon forbesi. Available at: http://doi.org/10.2305/IUCN.UK.2013-2. RLTS.T22724659A49758122.en. Access in: 19/03/2020.

Brown, L. \& Amadon, D. 1968. Eagles, hawks and falcons of the world. Great Britain, Hamlym Publishing Group. v. 1.

Cabanne,C.S.; d'Horta, F.M.;Sari, E.H.R.;Santos,F.R.\&Miyaki,C.Y.2008. Nuclearand mitochondrial phylogeography of the Atlantic forest endemic Xiphorhynchus fuscus (Aves: Dendrocolaptidae): biogeography and systematics implications. Molecular Phylogenetics and Evolution, 49(3): 760-773.

Dantas, G.P.M.; Cabanne, G.S. \& Santos, F.R. 2011. How past vicariant events can explain the Atlantic Forest biodiversity? In: Grillo, 0. \& Venera, G. (Eds.). Ecosystems Biodiversity. London, Intech. p. 429-442.

Dénes, F.V. 2009. Taxonomia e distribuição dos gaviões do gênero Leptodon Sundevall, 1836 (Aves: Accipitridae). (Masters Dissertation). São Paulo, Universidade de São Paulo.

Dénes, F.V.; Silveira, L.F.; Seipke, S.H.; Thorstrom, R.; Clark, W.S. \& Thiollay, J.M. 2011. The White-collared Kite (Leptodon forbesi Swann, 1922) and a review of the taxonomy of the Gray-headed Kite (Leptodon cayanensis Latham, 1790). The Wilson Journal of Ornithology, 123(2): 323-331.

Ferguson-Lees, J. \& Christie, D.A. 2001. Raptors of the world. Boston, Houghton Mifflin.

Foster, M.S. 1971. Plumage and behavior of a juvenile Gray-headed Kite. The Auk, 88(1): 163-166.

Girão, W.; Holderbaum, J.M. \& Nunes, F.P. 2013. Ocorrências cearenses do gaviãode-cabeça-cinza Leptodon cayanensis. Atualidades Ornitológicas, 171: 14-15.

Grantsau, R. 2010. Guia completo para identificação das aves do Brasil. São Carlos, Vento Verde.

Hellmayr, C.E. 1929. A contribution to the ornithology of northeastern Brazil. Field Museum of Natural History Zoological Series, 12(18): 235-501.
Hellmayr, C.E. \& Conover, B. 1949. Catalogue of birds of the Americas and the adjacent islands. Field Museum of Natural History Zoological Series, 13: $1-358$.

Isler, M.L. \& Maldonado-Coelho, M. 2017. Calls distinguish species of Antbirds (Aves: Passeriformes: Thamnophilidae) in the genus Pyriglena. Zootaxa, 4291(2): 275-294.

Leightom, G.M.; Lees, A.C. \& Miller, E.T. 2018. The hairy-downy game revisited: an empirical test of the interspecific social dominance mimicry hypothesis. Animal Behaviour, 137: 141-148.

Leite, G.A.; dos Santos, T.M.; Sampaio, S.; Filadelfo, T. \& Dénes, F.V. 2017. First documented record of White-collared Kite Leptodon forbesi in Bahia state, Brazil. Cotinga, 39: 95-98.

Maldonado-Coelho, M. 2012. Climatic oscillations shape the phylogeographical structure of Atlantic Forest fire-eye antbirds (Aves: Thamnophilidae). Biological Journal of the Linnean Society, 105(4): 900-924.

Naka, L.N. \& Brumfield, R.T. 2018. The dual role of Amazonian rivers in the generation and maintenance of avian diversity. Science Advances, 4(8): eaar8575. DOI

Pereira, G.A.; Araújo, H.F.P.; Azevedo-Jr., S.M.; Angelieri, C.C.S. \& Silveira, L.F. 2019. Distribution, threats and conservation of the White-collared Kite (Leptodon forbesi, Accipitridae), the most threatened raptor in the Neotropics. Papéis Avulsos de Zoologia, 59(28): 1-8. DOI

Pereira, G.A.; Dantas, S.M.; Silveira, L.F.; Roda, S.A.; Albano, C.; Sonntag, F.A.; Leal, S.; Periquito, M.C.; Malacco, G.B. \& Lees, A.C. 2014. Status of the globally threatened forest birds of northeast Brazil. Papéis Avulsos de Zoologia, 54(14): 177-194.

Pinto, 0.M.0. 1978. Novo Catálogo das Aves do Brasil: primeira parte: Aves não Passeriformes e Passeriformes não Oscines, com exclusão da família Tyrannidae. São Paulo, Empresa Gráfica Revista dos Tribunais.

Prum, R.0. 2014. Interspecific social dominance mimicry in birds. Zoological Journal of the Linnean Society, 172(4): 910-941.

Rêgo, M.A.; Del-Rio, G. \& Silveira, L.F. 2014. A taxonomic review of Picumnus exilis (Aves: Picidae) reveals an underestimation of Piculet species diversity in South America. Journal of Ornithology, 155(4): 853-867.

Sagot-Martin, F.; Lima, R.D.; Pacheco, J.F.; Irusta, J.B.; Pichorim, M. \& Hassett, D.M. 2020. An updated checklist of the birds of Rio Grande do Norte, Brazil, with comments on new, rare, and unconfirmed species. Bulletin of the British Ornithologists' Club, 140(3): 218-298.

Seipke, S.H.; Dénes, F.V.; Pallinger, F.; Thorstrom, R.; Thiollay, J.M.; Silveira, L.F. \& Clark, W.S. 2011. Field identification of White-collared Kite Leptodon forbesi and similar species in northeast Brazil. Neotropical Birding, 8: 29-39.

Sick, H. 1997. Ornitologia brasileira. Rio de Janeiro, Nova Fronteira.

Silva, C. \& Lima, J.0. 2016. Primeiro registro documentado do gavião-depescoço-branco, Leptodon forbesi, para o Parque Nacional Serra de Itabaiana, Sergipe, Brasil. Atualidades Ornitológicas, 193: 25.

Silva, J.M.C.; Sousa, M.C. \& Castelletti, C.H.M. 2004. Areas of endemism for passerine birds in the Atlantic forest, South America. Global Ecology and Biogeography, 13: 85-92.

Soares, L.M.S.; Bates, J.; Carneiro, L.S.; Santos, M.P.D. \& Aleixo, A. 2019. Molecular systematics, biogeography and taxonomy of forest-falcons in the Micrastur ruficollis species complex (Aves: Falconidae). Journal of Avian Biology, 50(4): 01943.

Thiollay, J.M. 1994. Family Accipitridae. In: del Hoyo, J.; Elliott, A. \& Sargatal, J. (Eds.). Handbook of the Birds of the World. Barcelona, Lynx Edicions. v. 2, p. $52-205$.

Weir, J.T. \& Price, M. 2011. Andean uplift promotes lowland speciation through vicariance and dispersal in Dendrocincla woodcreepers. Molecular Ecology, 20: 4550-4563. 